\title{
EFFICACY OF INTERFERON THERAPY IN PATIENTS OF CHRONIC HEPATITIS B VIRAL INFECTION TREATED AT MH RAWALPINDI
}

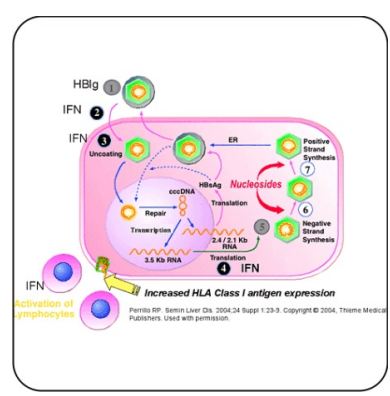

\author{
DR. MOHAMMAD ABDUL NAEEM \\ CMH Abbottabad \\ DR. IMRAN KHAN \\ Chitral Scouts
}

\section{DR.JAMAL WARIS \\ CMH Gilgit}

\author{
Dr. Muhammad Usman \\ CMH Abbottabad
}

\begin{abstract}
Background: The consequences of acute and chronic HBV infection are major public health problems. These infections may progress to cirrhosis, liver failure, and Hepatocellular carcinoma Treatment of chronic replicative hepatitis $B$ virus (HBV) infection is aimed at stopping viral replication and preventing the development of chronic liver disease. Objective: To determine the efficacy of Interferon therapy in patients of chronic Hepatitis $B$ treated at MH Rawalpindi, by comparison of PCR for HBV DNA before and after Interferon therapy. Study Design: Quasi-experimental study. Place and duration of study: Military Hospital, Rawalpindi from July 2003 to December 2005. Subjects and Methods: The efficacy of a 4-month course of subcutaneously administered human recombinant interferon Alfa was studied. A total of 50 patients of proven chronic viral hepatitis $B$ with presence of hepatitis $B$ surface antigen and hepatitis $B$ virus DNA (HBV DNA) in the serum were enrolled over the span of 30 months. All patients were treated with 5 mega units of recombinant interferon alfa- $2 b$ subcutaneously once daily for 4 months. PCR for HBV DNA was performed at the end of fourth month in treated patients as a predictor of response to interferon therapy. Results: The treatment was well tolerated, only in three patients treatment was ceased due to severe depression while none of the other patient required dosage reduction or cessation of treatment because of side effects. In 22 treated persons (44.0\%) PCR for HBV DNA becomes negative showed response to treatment. This finding is statistically significant ( $p$ less than 0.05). Conclusion: Interferon Alfa has significant efficacy in chronic Hepatitis B. Patients of chronic Hepatitis B in whom Interferon therapy is not contraindicated should be treated with Interferon Alfa to avoid long term complication of infection.
\end{abstract}

Key words: Chronic Hepatitis B, HBV, Interferon Alfa, PCR.

\section{INTRODUCTION}

Worldwide, the consequences of acute and chronic HBV infection are major public health problems ${ }^{1}$. It is estimated that approximately 350 million people have 
chronic HBV infection ${ }^{1-6}$. Although HBV can be prevented by vaccination, it remains an important cause of morbidity and mortality. The spectrum of clinical manifestations of HBV infection varies in both acute and chronic disease. During the acute phase, manifestations range from subclinical or anicteric Hepatitis to icteric hepatitis and, in some cases, fulminant hepatitis. During the chronic phase, manifestations range from an asymptomatic carrier state to chronic hepatitis, cirrhosis, and Hepatocellular carcinoma. Extrahepatic manifestations also can occur with both acute and chronic infection. About a quarter of carriers develop serious liver disease as a result of the infection, around 1000,000 persons die annually of HBV-related liver disease ${ }^{1,4}$. Viral hepatitis is the major cause of chronic liver disease ${ }^{1,3,4}$. Untreated, these infections may progress to cirrhosis, liver failure, and Hepatocellular carcinoma ${ }^{1,3,4,7}$. Because of these complications, five-year survival rates may be as low as 55 percent $^{8}$. Ultimately, 40 percent of Asian men with chronic hepatitis B die of either complications of cirrhosis or Hepatocellular carcinoma ${ }^{9}$. The objective of treating chronic HBV infection is to halt progression of liver injury by suppressing viral replication or eliminating infection, which will prevent progression to cirrhosis and $\mathrm{HCC}$ and prolongation of survival. Interferon therapy causes loss of HBeAg and HBV DNA in approximately a third of treated patients, ${ }^{1,9,16}$ and the loss of these markers of active viral replication is associated with improvements in hepatic histology and ALT levels. In general, seroconversion from $\mathrm{HBeAg}$ to hepatitis $B$ e antibody (anti-HBe) is associated with disappearance of HBVDNA in serum and remission of liver disease ${ }^{9}$. Improvement is usually sustained well after therapy has been discontinued ${ }^{4,18-19}$. Interferon treatment is an independent factor associated with a $50 \%$ reduction in the risk of developing Hepatocellular carcinoma ${ }^{20}$. The effects of Interferon therapy should be monitored clinically, in addition, serum aminotransferase concentrations should be measured at two to four week intervals, with serologic assay for HBV DNA performed at the start of therapy, the end of therapy, and six months later ${ }^{1,21}$. HBV infection is endemic in Pakistan with a difference of frequency in different communities, ${ }^{22}$ no authentic data is available, ${ }^{21}$ but it is estimated that there are about 9 million hepatitis $\mathrm{B}$ carriers in Pakistan ${ }^{23-25}$. In Pakistan significant data about response of Interferon alpha treatment is not available, In two local studies, response to interferon treatment found $46-50 \%{ }^{26,27}$. This study is design to evaluate efficacy of Interferon-alpha in chronic hepatitis $B$ infection.

\section{PATIENTS AND METHODS}

The data was collected from adult patients of all ages with already diagnosed chronic hepatitis $B$ virus infection and positive PCR of HBV DNA, presented at Military Hospital Rawalpindi. Those patients who was already treated with interferon therapy or simultaneously infected with Hepatitis $C$ virus, had other chronic illness like renal failure, cardiac failure, anemia or who had cirrhosis were not included in the study. Data was entered in proforma designed to conduct the study. Detailed clinical examination was performed on every patient to evaluate comorbidity. 50 cases were identified among them 42 $(84 \%)$ were male and $8(16 \%)$ female, prior promission was sought for sanction of interferon therapy from medical directorate $\mathrm{GHQ}$. Interferon Alfa in the dose of 5 million units subcutaneously daily for four months was administered in all cases and PCR for HBV DNA was perfomed at 0 and $4^{\text {th }}$ months at Armed Forces Institute of Pathology (AFIP) Rawalpindi, using $2^{\text {nd }}$ generation ELLISA technique. Sera were collected from brachial veins of all cases under strict aseptic measures and LFT's and FBC was performed at AFIP Rawalpindi on monthly basis to monitor response to treatment and adverse effects of therapy. Those patients in whom therapy was discontinued due to any reason were excluded from our study. Patients were disposed off as per hospital policy after 4 months. There was no further follow up.

The data was compiled and analyzed by using SPSS version 10 on computer. Rationale descriptive statistics, frequency and percentage were computed for 
presentation of qualitative variables like sex, laboratory findings like PCR for HBV DNA before and after interferon therapy etc, Mc Nemer test of significance was applied to compare the PCR findings before and after interferon therapy at $P<0.05$ level of significance. Qualitative variables like age etc, were presented by means \pm standard deviation.

\section{RESULTS}

A total of 50 patients of proven chronic hepatitis $B$ were enrolled at MH Rawalpindi. The mean age was 36 years with standard deviation from mean being 6.07. The males were $84 \%$ while females being $16 \%$ (Fig-1.).

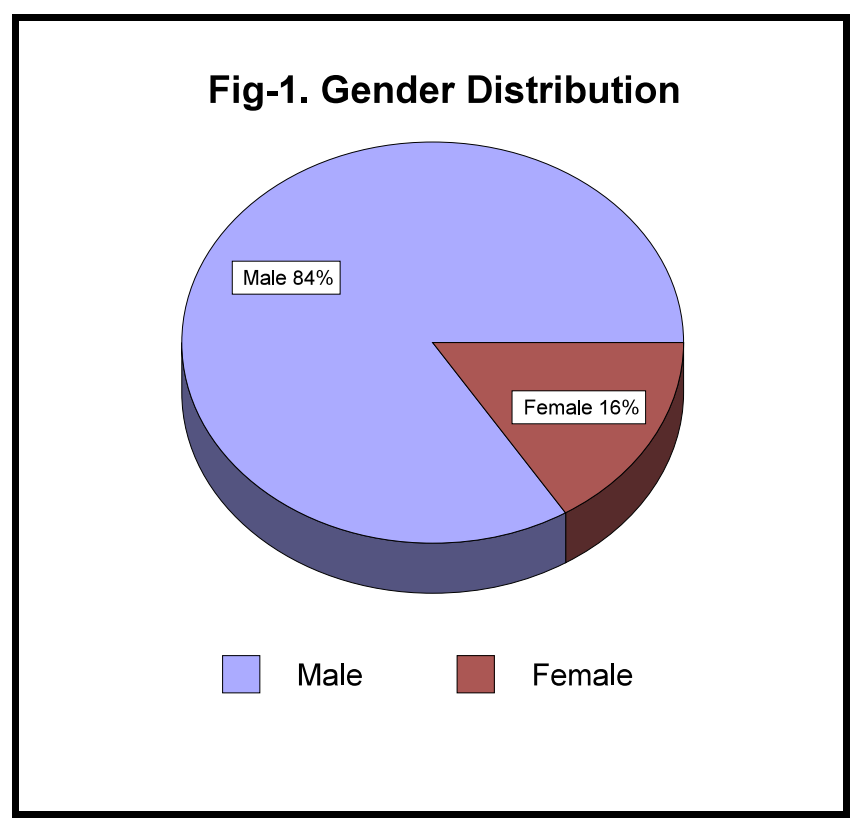

All of them were treated with interferon Alfa 5 mega units subcutaneously once daily for four months. PCR for HBV DNA was performed at zero and at the end of fourth month in treat group as a predictor of response to interferon therapy. The treat was well tolerated, only in three patients treatment was ceased due to severe depression and they were excluded from study, none of the other patient required dosage reduction or cessatio of treatment because of side effects. In 22 treated persons (44.0\%) PCR for HBV DNA becomes negative showed response to treatment (Fig-2.). This finding is statistically significant $(p<0.05)$.

Fig-2. PCR after treatment

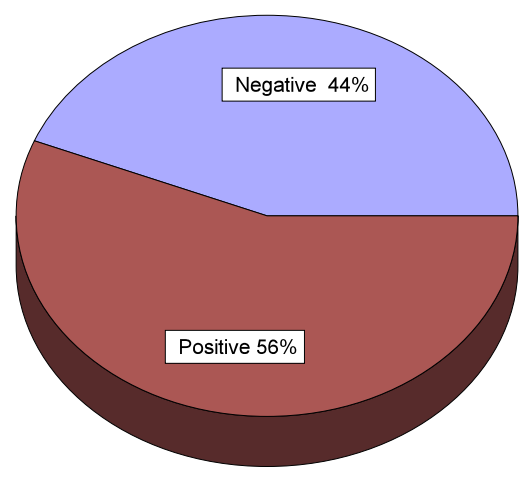

Negative $\square$ Positive

\section{DISCUSSION}

In our study we consider PCR for HBV DNA as marker of response to Interferon therapy. In twenty two Out of fifty treated patients (44.0\%), Serum HBV DNA levels were below the lower limit of detection, after four months Interferon treatment. This result is statistically significant $(P<0.05)$. Our results are comparable to contemporary studies of Raptopolou M, et a ${ }^{28}$ and US National institute of health trials ${ }^{29}$. Another study conducted by Mullar M, et $\mathrm{al}^{30}$, response was $32.4 \%$ with 3 mega units thrice weekly.

Increases in dose and duration of treatment can increase the number of symptoms of toxicity ${ }^{31-32}$. Our results with four months treatment are comparable with six month regimen ${ }^{28}$ while HBV DNA clearance occurred in more patients as compared in low dose regimen trial ${ }^{30}$.

The tolerability and safety profiles of interferon alfa were satisfactory, and there were no unexpected adverse effects Although depression induced by interferon was 
developed in 20 treated patients, only in three out of them, treatment was ceased due to severe depression and they were excluded from study, while in rest of others, it was nothing more than minor feelings of sadness and no patient receiving interferon meet the psychiatric criteria for major depression. These criteria include diminished appetite, weight loss, insomnia or hypersomnia, agitation or mental retardation, fatigue, and diminished ability to concentrate.

The safety profile of Interferon Alpha also compares favorably with the profiles described in previous studies of conventional interferon alfa in patients with chronic hepatitis $B^{3-34}$. It is noteworthythat no patienthad hepatic decompensation during treatment.

We observed very trivial side effects like flu like symptoms, nausea, vomiting which observed during initial weeks of treatment, responded well to symptomatic treatment, Di Biscigle observed significant side effect, and even treatment was stopped in few patients due to intensities of side effects ${ }^{14}$.

The objective of treating chronic HBV infection is to halt progression of liver injury by suppressing viral replication or eliminating infection, which will prevent progression to cirrhosis and $\mathrm{HCC}$ and prolongation of survival. Although most carriers will not develop hepatic complications from chronic hepatitis B, $15-40 \%$ develop serious squeal during there life time.

Patients who were successfully treated with interferon Alfa, as indicated by the clearance of $\mathrm{HBeAg}$ and HBV DNA (on dot blot hybridization), had a better long-term clinical outcome than those in whom these markers of viral replication persisted. The frequency of death, liver transplantation, and severe clinical complications due to cirrhosis was significantly lower among the patients with elimination of $\mathrm{HBeAg}$ than among those with persistence of $\mathrm{HbeAg}$. Our data thus provide further evidence of a benefit of interferon alfa in patients with chronichepatitis $B$ and may also be used in cost-benefit and cost- effectiveness. Our conclusions about the clinical benefit of the interferon-induced elimination of markers of viral replication are supported by the results of previous studies of the natural history of chronic hepatitis $B^{36,37,38,39}$. The spontaneous seroconversion and HBV DNA elimination is associated withan improvement in the clinical outcome of untreated patients. Nevertheless, the rates of elimination of $\mathrm{HbeAg}$ and HBV DNA, as well as of the normalization of alanine aminotransferase levels, were markedly higher among the interferon-treated patients than among the untreated patients. These results have been reported in randomized trials, ${ }^{34-39}$ most of which, however, had a considerably shorter follow-up. In previousstudies, continued viral replication (persistent $\mathrm{HBeAg}$ ) was associated with substantial mortality and morbidity during approximately five years of follow-up ${ }^{39,40}$. The benefit to patients in whom HBeAg was cleared after interferon therapy could be due to a selection bias, however, and not to interferon therapy. There is no experimental or epidemiological support for this hypothesis, but the issue cannot be definitely settled, because it would be unethical to withhold long-term treatment with interferon alfa from patients with chronic hepatitis $\mathrm{B}$. Thus, for comparisons, we have to rely on data from patients who remained untreated for a variety of reasons and on data about the natural history of chronic hepatitis $B$ before interferon therapy became available ${ }^{36-40}$. Nevertheless, both types of data support the hypothesis that treatment with interferon improves the clinical outcome, so long as it eliminates $\mathrm{HbeAg}$ analyses.

As we did not follow the patients after completion of treatment therefore not able to comment on persistency of seroconversion and recurrence of disease but studies in international literature showed Improvement is usually sustained well after therapy has been discontinued ${ }^{4,13-17}$. Data on long term outcome of patients treated for chronic hepatitis B showed that twenty to fifty percent of long term responders, defined by normal ALT levels and undetectable HBV DNA by hybridization assay cleared

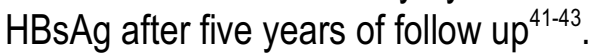


We do not have significant numbers of studies to determine efficacy of Interferon in our population. In one study conducted by Sheikh WM, et al ${ }^{26}$ response was $46 \%$, which is comparable to our study. Our data thus provide evidence of benefit of interferon alfa in our population with chronichepatitis $B$ similarly results of our study are comparable to other studies in the international literature.

\section{CONCLUSION}

Our study, despite its shortcomings, suggests that, Interferon Alfa has significant efficacy in chronic Hepatitis B. To avoid long term complication of infection, Patients of chronic Hepatitis B in whom Interferon therapy is not contraindicated, should be treated with Interferon Alfa.

To determine the efficacy of interferon in our population, a concerted effort should be made to form a registry of treated patients in our population, to know whether viral replication has been permanently eradicated and the risks for developing the long term sequelae of this disease have truly been reduced.

\section{REFERENCES}

1. Mahoney FJ. Update on diagnosis, management and prevention of hepatitis $B$ Virus infection. Clin Microbiol Rev 1999; 12: 351-66.

2. Wai CT, Lok ASF. Treatment of hepatitis B. J Gastroenterol 2002; 37:771-8.

3. Gow PJ, Mutimer D, Treatment of chronic hepatitis BMJ $2001 ; 323: 1164-7$.

4. Lee WM, Hepatitis B virus infection. N Engl J Med 1997; 337: 1733-45.

5. Hepatitis B. Fact sheet WHO/2004.Geneva. World Health Organization,Oct 2000.(Accessed January 9 2004, at http://www.who.int/inf-fs/en/fact204.htm).

6. Marcellin P, Chang TT, Lim SG, Tong JM, Sievert W, Shifman ML, et al. Adefovir Dipivoxil for the treatment of hepatitis $\mathrm{Be}$ antigen positive chronic hepatitis. $\mathrm{N}$ Engl J Med 2003; 348: 808-16.
7. Younas BB. Prevalence of hepatitis B in patients suffering from chronic liver disease. Mother Child 2000; 38(2): 68-71.

8. Weissberg Jl, Andres LL, Smith $\mathrm{Cl}$, et al. Survival in chronic hepatitis $B$ : an analysis of 379 patients. Ann Intern Med 1984; 101:613-6.

9. Beasley RP, Hwang L-Y, Lin CC, Chien CS. Hepatocellular carcinoma and hepatitis B virus: a prospective study of $\mathbf{2 2} \mathbf{7 0 7}$ men in Taiwan. Lancet 1981; 2:1129-33.

10. Beasley RP. Hepatitis B virus, the major etiology of hepatocellular carcinoma. Cancer 1988; 61:1942-56.

11. Terrault NA, Wright TL. Therapy for chronic hepatitis $B$ infection. Adv Exp Med Biol. 1996;394:189-205.

12. Brook MG, McDonald JA, Karayiannis $P$, Caruso $L$, Forster $G$, Harris JR, et al. Randomized controlled trial of interferon Alfa 2A (rbe) (Roferon-A) for the treatment of chronic hepatitis $B$ virus (HBV) infection: factors that influence response. Gut 1997; 30:1116-22.

13. Hoofnagle JH. Therapy of acute and chronic viral hepatitis. Am FamPhysician2004;69:1863.

14. Di Bisceglie AM, Fong TL, Fried MW, Swain MG, Baker B, Korenman J, et al. A randomized, controlled trial of recombinant alpha-interferon therapy for chronic hepatitis B. Am J Gastroenterol 1993;88:1887-92.

15. Ganem D, Prince AM. Hepatitis B virus infection Natural history and clinical consequences. $N$ Engl J Med 2004; 350: 1118-29.

16. Wong DK, Cheung AM, O'Rourke K, Naylor CD, Destky AS, Heathcote. Effect of alpha-interferon in patients with hepatitis $B$ e antigen-positive chronic hepatitis $B$ : a meta-analysis. Ann Intern Med 1993;119:312-23.

17. Korenman J, Baker B, Waggoner J, Everhart JE, Di Bisceglie AM, Hoofnagle JH. Long-term remission of chronic hepatitis $B$ after alpha-interferon therapy. Ann Intern Med 1991;114:629-34.

18. Carreño V, Castillo I, Molina J, Porres JC, Bartolomé J. Long-term follow-up of hepatitis B chronic carriers who responded to interferon therapy. J Hepatol 1992; 
15: $102-6$.

19. Niederau C, Heintges T, Lange S. Long-term follow-up of $\mathrm{HBeAg}$ positive patients treated with interferon alfa for chronic hepatitis B. N EnglJ Med 1996;334:1422-27.

20. Yoshida H, Shiratori $Y$, Moriyama M. Interferon therapy reduces the risk for hepatocellular carcinoma: national surveillance program of cirrhotic and noncirrhotic patients with chronic hepatitis $C$ in Japan. Ann Intern Med 1999;131:174-81.

21. Hoofnagle JH. The Treatment of Chronic Viral Hepatitis. N Engl J Med1997;336:347-56.

22. Ali N, Khattak J. Prevalence of hepatitis B surface antigen and hepatitis $C$ antibodies in young healthy adults. Pakistan J Pathol 2002; 13(2):3-6.

23. Akhtar J. Surgeon and hepatitis B and C (editorial). J Coll Physician Surg Pak 2004; 14: 327-8.

24. Hussain.K.B. Treatment options for chronic hepatitis B(editorial). J Pak Med Assoc 2001; 51: 306-6.

25. Salam A. Prevalence of the HBsAg cases. Professional Med J 2003;10(1):23-25.

26. Shaikh WM, Shah SR, Nisa NU. Results of six months treatment of chronic hepatitis $B$ with recombinant Interferon Alpha therapy. J Coll Physician Surg Pak $1997 ; 7 ; 145-47$.

27. Khan PM, Humayun M, Jamal SS, Baseer A. Response to chronic $B$ and $C$ viral hepatitis to Ifn-Alfa. J Postgrad Med Inst 1999; 13(1): 104-8.87; 5:45.

28. Raptopoulou M, Orphanou H, Vrettou H, Akribiadis E, Chadzikonstantinou L, Goulis $G$. Interferon treatment of chronic active hepatitis $B$ : effect of a six month treatment regimen. Gut 1993; 34:102-3.

29. Perrillo RP. . Interferon for hepatitis B: US experience. Gut 1993; 34: 95-6.

30. Muller R, Baumgarten R, Markus R, Schulz M, Wittenberg $H$, Hintsche-Kilger $B$, et al. Treatment of chronic hepatitis B with interferon alpha-2b. Dtsch Med Wochenschr 1990; 16: 403-7.
31. Quesada JR, Hawkins M, Horning S, Alexanian R, Borden $E$, Merigan T, et al. A collaborative phase I-Il study of recombinant DNA-produced leukocyte interferon (clone A) in metastatic breast cancer, malignant lymphoma, and multiple myeloma. Am J Med. 1984; 77:427-32.

32. Silver HK, Connors JM, Salinas FA. Prospectively randomized toxicity study of high-dose versus lowdose treatment strategies for lymphoblastoid interferon. Cancer Treat Rep. 1985; 69:743-50.

33. Manesis EK, Hadziyannis SJ. Interferon treatment and retreatment of hepatitis $B$ e antigen-negative chronic hepatitis B. Gastroenterology 2001; 121:101-109.

34. Lampertico $P$, Del Ninno E, Vigano $M$, et al. Long-term suppression of hepatitis $B$ e antigen-negative chronic hepatitis $B$ by 24-month interferon therapy. Hepatology 2003; 37:756-763.

35. Hoofnagle JH, Peters M, Mullen KD, et al. Randomized, controlled trial of recombinant human alpha-interferon in patients with chronic hepatitis B. Gastroenterology 1988; 95:1318-25.

36. Alexander GJM, Brahm J, Fagan EA, et al. Loss of HBsAg with interferon therapy in chronic hepatitis $B$ virus infection. Lancet 1987; 2:66-9.

37. Brook MG, McDonald JA, Karayiannis $P$, et al. Randomised controlled trial of interferon alfa $2 A$ (rbe) (Roferon-A) for the treatment of chronic hepatitis $B$ virus (HBV) infection: factors that influence response. Gut 1989; 130:1116-1122.

38. Perrillo RP, Schiff ER, Davis $\mathrm{GL}$, et al. A randomized, controlled trial of interferon alfa-2b alone and after prednisone withdrawal for the treatment of chronic hepatitis B. N Engl J Med 1990; 323:295-301.

39. Perrillo RP. Antiviral therapy of chronic hepatitis $B$ : past, present, and future. J Hepatol 1993; 17:56-63.

40. Tine F, Liberati A, Craxi A, Almasio P, Pagliaro L. Interferon treatment in patients with chronic hepatitis B: a meta-analysis of the published literature. J Hepatol 1993; 18:154-162.

41. Eddy, DM. A manual for assessing health practices and designing practice guidelines. American college of 
physicians, Philadelphia 1996. P-1.

42.

Paptheoridis, GV, Manesis. The longterm outcome of Interferon alfa treated and untreated patients with HBeAg negative chronic hepatitis B. J Hepatol 2001;
$34: 2006$.

43. Lampertico, $P$, Dell Ninno, et al. Long term suppression of $\mathrm{HBeAg}$ negative chronic hepatitis B by 24 months Interferon therapy. Hepatology 2003; 37: 756.

\section{WILL BE AVAILABLE SOON}

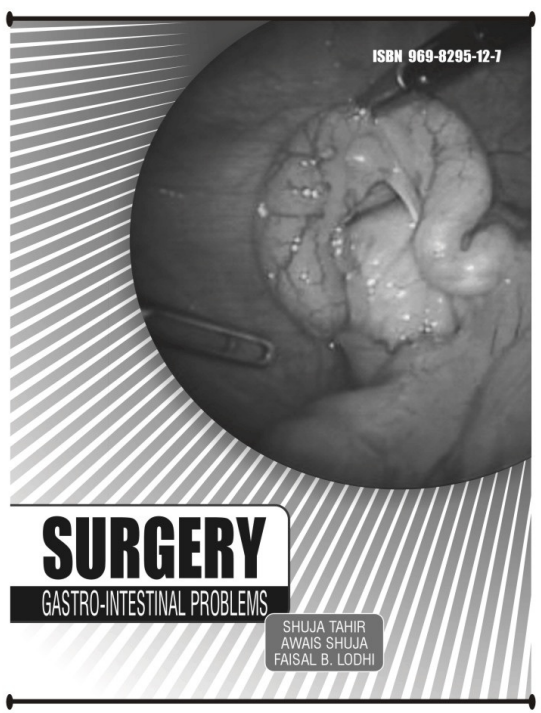

All gastro-intestinal-problems

Easy solutions explained in simple language

Recent advancements and up to date work up

All given in this book. It is helpful to undergraduates and postgraduates.

$$
\begin{gathered}
\text { Published by: } \\
\text { WDEPENDENT PUBISHING HOUSE } \\
\text { Jinnah Colony, Faisalabad. } \\
\text { Tel: 092-41-2617122-24, 2623412 } \\
\text { Fax: 092-41-2623413 } \\
\text { www.theprofesional.com } \\
\text { publication@theprofesional.com, } \\
\text { editor@theprofesional.com }
\end{gathered}
$$

